\title{
Renal replacement lipomatosis of the right kidney
}

\author{
Vishal Ratkal, Arun Chawla, Dilip Kumar Mishra, Suprita Krishna
}

Department of Urology, Kasturba Medical College, Manipal, Karnataka, India

\section{Correspondence to} Dr Arun Chawla, urologyarun@yahoo.com

Accepted 6 December 2014

\section{DESCRIPTION}

Renal replacement lipomatosis (RRL) of the kidney, also known as replacement fibrolipomatosis, is an advanced form of renal sinus lipomatosis that usually occurs unilaterally. Infection, long-term hydronephrosis and calculi are associated with severe renal parenchymal atrophy followed by replacement of fat in renal sinus, hilum and perirenal spaces. $^{1}{ }^{2}$ It occurs in the 6 th and 7 th decade. $^{3} 4$ Pathologically, the kidney is enlarged with normal shape and has a gross, fibrofatty appearance. The renal cortex is atrophied, with varying degrees of hydronephrosis or pyonephrosis and calculi. Microscopically, marked proliferation of fat in the renal sinus, with extremely large fat cells not permeating the renal parenchyma is seen. CT scan is the most accurate method of demonstrating the distinctive features of RRL. The abundant fatty tissue, characteristic distribution of fat within renal sinus and perinephric space with calculi and atrophied parenchyma can be easily appreciated. ${ }^{4}$ The kidney is non-functional and
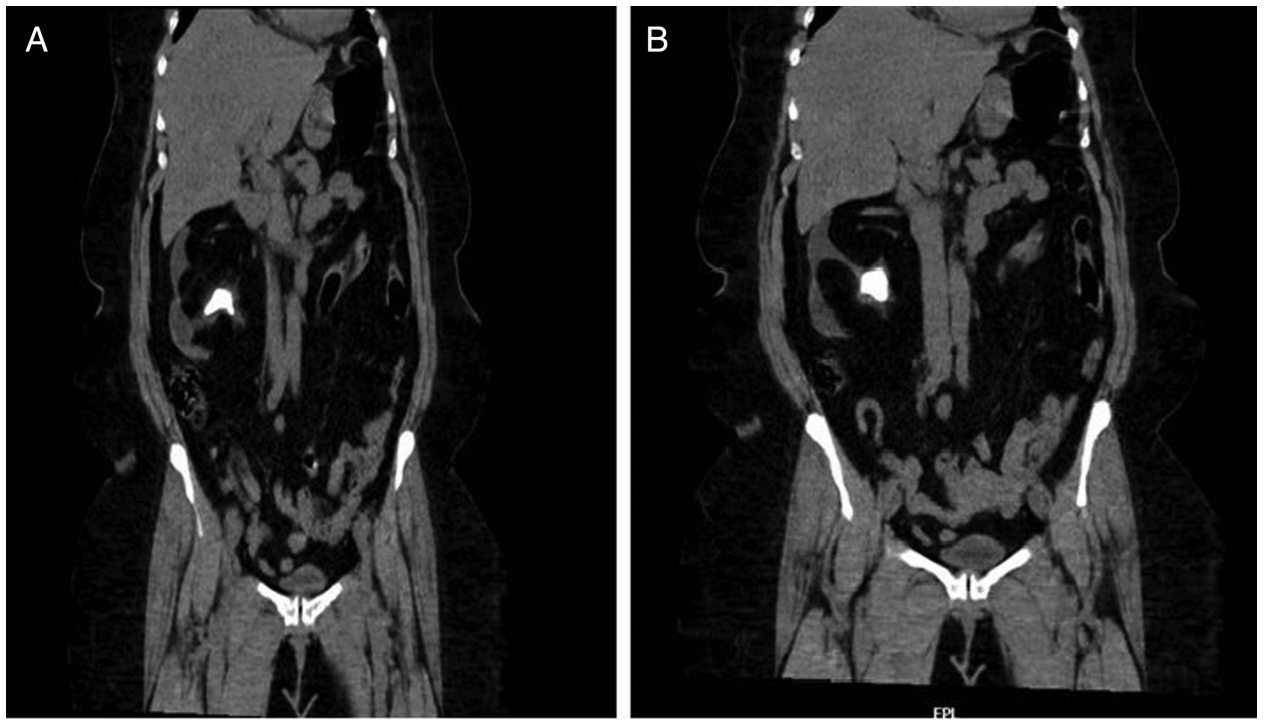

Figure 1 ( $A$ and $B$ ) Coronal section of the right kidney showing diffuse thinning of the parenchyma with moderate hydronephrosis and a calculus measuring $2.7 \times 1.2 \mathrm{~cm}$ in the right renal pelvis. There is proliferation of renal sinus fat on the right.
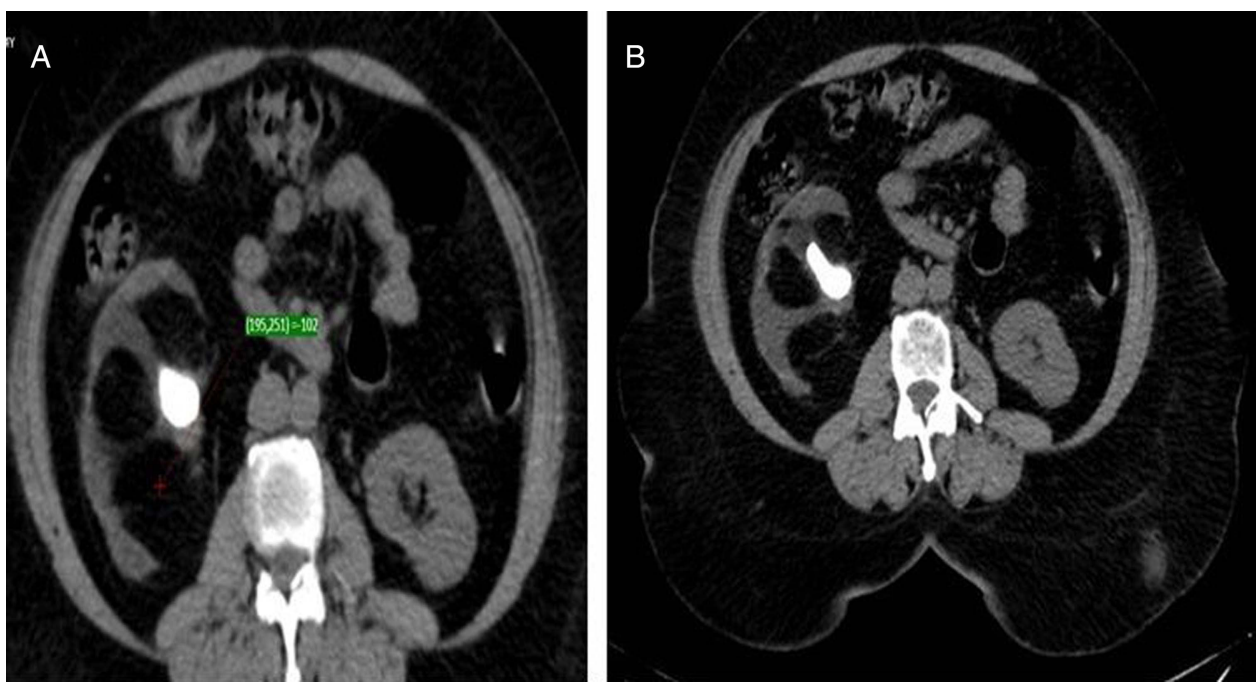

Figure 2 ( $A$ and $B$ ) Axial section of the right kidney showing enlarged, diffuse parenchymal thinning with moderate hydronephrosis and a calculus measuring $2.7 \times 1.2 \mathrm{~cm}$ in the right renal pelvis. There is proliferation of renal sinus fat on the right. The left kidney is normal in size and attenuation. 


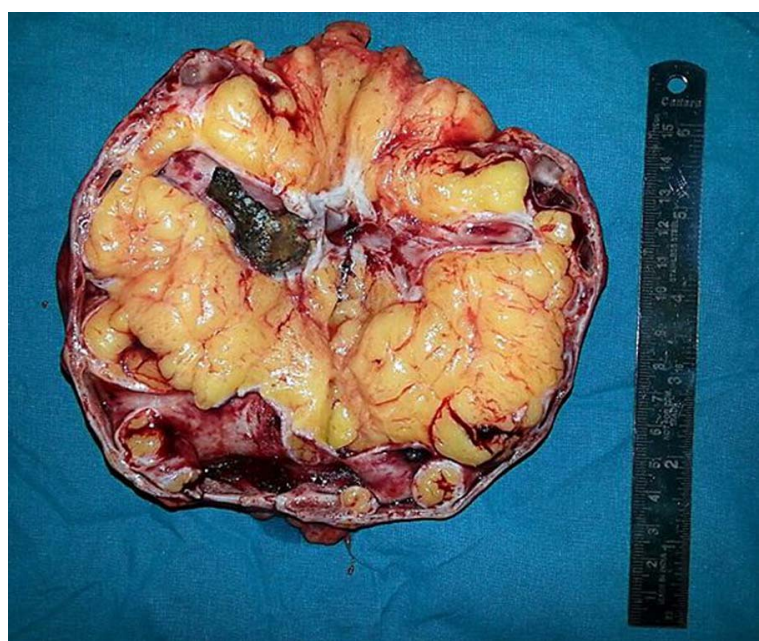

Figure 3 Cut section of the right kidney specimen weighing $532 \mathrm{~g}$ and measuring $15 \times 9 \times 8.5 \mathrm{~cm}$, showing irregular cortical surface and focal scarring with thinned out cortex and dilated pelvicalyceal system containing calculus measuring $2.7 \mathrm{~cm}$. Gross fatty infiltration is seen.

needs nephrectomy in the majority of cases. This condition is very rare and needs to be differentiated from lipomas, xanthogranulomatous pyelonephritis, angiomyolipoma and liposarcomas. Because of lack of suspicion it is hardly ever diagnosed preoperatively.

We present a case of a 54-year-old woman presented with dull aching right loin pain for 3 months. Plain X-ray of the kidney ureter bladder (KUB) showed right partial staghorn calculus. Ultrasound of the abdomen revealed thinned out parenchyma with calculus in pelvis and inferior calyx measuring approximately $2.7 \mathrm{~cm}$ and ill-defined hyperechoic tissue within the renal parenchyma on the right. Plain CT of the KUB (figures $1 \mathrm{~A}, \mathrm{~B}$ and $2 \mathrm{~A}, \mathrm{~B}$ ) showed right kidney with diffuse severe thinning of the parenchyma with moderate hydronephrosis with a calculus measuring $2.7 \times 1.2 \mathrm{~cm}$ in the right renal pelvis. Hypodense areas simulating fat values $(-80$ to -130$)$ were seen throughout the entire renal area. The left kidney was normal. Preoperative diagnosis of RRL was made. DTPA (diethylene triamine penta-acetic acid) renogram displayed a poorly functioning right kidney (5\%), with normal functioning left kidney. The patient underwent right simple nephrectomy under general anaesthesia with uneventful postoperative course. Gross specimen (figure 3) showed abundant fatty replacement of the kidney with calculus. Histopathology report confirmed RRL (figure 4A, B). The case is being presented for its extreme rarity, to show the importance of ruling out other differential diagnoses and to highlight that correct preoperative diagnosis can be made if suspected.

\section{Learning points}

- Renal replacement lipomatosis (RRL) is very rare and often not suspected preoperatively.

- CT findings are characteristic and often differentiate RRL from other conditions.

- Histopathology is confirmatory.

- Usually, RRL is associated with a non-functioning kidney and nephrectomy is indicated.

Competing interests None.

Patient consent Obtained.

Provenance and peer review Not commissioned; externally peer reviewed.

\section{REFERENCES}

1 Ambos MA, Bosniak MA, Gordon R, et al. Replacement lipomatosis of the kidney. AJR Am J Roentgenol 1978;130:1087-91.

2 Hurwitz RS, Benjamin JA, Cooper JF. Excessive proliferation of peripelvic fat of the kidney. Urology 1978;11:448-56.

3 Karasick S, Wechsler RJ. Case 23: replacement lipomatosis of the kidney. Radiology 2000;215:754-6.

$4 \mathrm{Xu}$ Y, Liu RL, Zhang ZH, et al. Renal replacement lipomatosis. Eur Surg Res 2006;38:385-7.
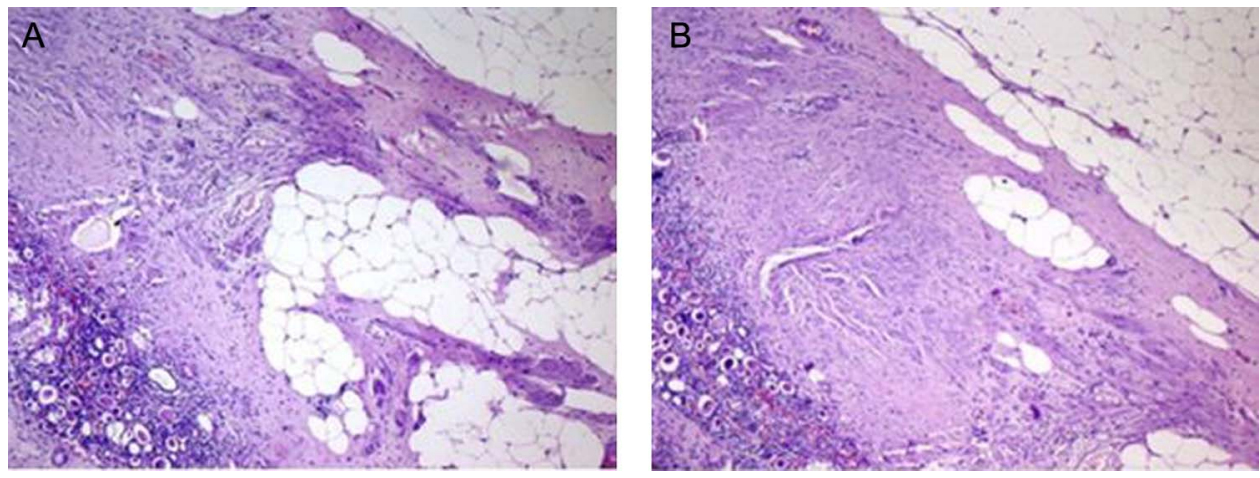

Figure 4 (A and B) Photomicrograph (A) showing sclerosed and compressed tubules (white solid arrow) and (B) showing lobules of adipocytes (black arrow) with a periphery of the renal cortical parenchyma, H\&E $\times 200$. 
Copyright 2015 BMJ Publishing Group. All rights reserved. For permission to reuse any of this content visit http://group.bmj.com/group/rights-licensing/permissions.

BMJ Case Report Fellows may re-use this article for personal use and teaching without any further permission.

Become a Fellow of BMJ Case Reports today and you can:

- Submit as many cases as you like

- Enjoy fast sympathetic peer review and rapid publication of accepted articles

- Access all the published articles

- Re-use any of the published material for personal use and teaching without further permission

For information on Institutional Fellowships contact consortiasales@bmjgroup.com

Visit casereports.bmj.com for more articles like this and to become a Fellow 